\title{
Branding the revival of knowledge
}

\section{Leuven University Press and the renaissance of typography, 1759}

Pierre Delsaerdt, University of Antwerp

\begin{abstract}
In 1759, a patented University Press was established in Leuven. This article examines the historical context in which the idea of a university press took root. It describes into more detail the roles played by the university librarian Corneille-François Nelis and by the head of the Privy Council in Brussels, Patrice-François de Neny. Their correspondence proves that the librarian in particular considered the new press as an instrument to improve the quality of academic publishing, not least by paying the utmost attention to the typographic design of the press's publications. Nelis introduced neoclassical aesthetics in the typographical world of the Southern Low Countries. His views call to mind the concept of branding. The article then explores how this modern concept can be used to better understand the press's marketing strategy during its first years, and to explain why it failed to realize the ambitions of its founders.
\end{abstract}

\section{Keywords}

Publishing history - University history - Typographic design - Neoclassical typography - Corneille-François Nelis - Patrice-François de Neny - Leuven University Press

In the summer of 1759, the government of the Southern Low Countries decreed that a university press would be established in Leuven. At the time, Leuven was the only university town in the country, which itself was part of the Austrian-Habsburg Empire. The idea of a university press had been conceived by two men: PatriceFrançois de Neny, head of the Privy Council in Brussels, and Corneille-François Nelis, the university librarian. They both considered that the new publishing house would be a powerful means to modernize teaching and research at Leuven University. In the librarian's view, in particular, the Typographia Academica would boost the standard of scholarly publishing, especially by paying the utmost attention to the quality of the type and paper used. As Nelis stated:

The imprint Typis Academicis must indicate nothing but quality of content and beauty of execution [...]. In scholarly Europe, it will be a guarantee of the quality and the beauty of a book to have been printed on the university's presses. ${ }^{1}$

\footnotetext{
* This is an edited version of the paper I presented at the conference The Beauty of Letters: text, type and communication in the eighteenth century (The University of Birmingham 14-15 March 2015).

${ }^{1}$ 'L'inscription Typis Academicis, qui ne doit rien annoncer que de bon pour le fond, et de beau pour l'exécution. [...] Ce sera un préjugé dans l'Europe savante pour la bonté et la beauté d'un ouvrage, d'être sorti des presses de l'université.' Annex to a letter by C.F. Nelis to P.F. de Neny from Leuven, 21 May 1759 (Leuven, State Archives, Ancient University of Leuven, 229).
} 
In this and other letters, the Leuven librarian regularly proclaimed his belief in typographical quality as an incarnation of the press's innovative and enlightened spirit. His comments call to mind the modern concept of branding as a marketing instrument. What was the historical background of this initiative? How was it that a university librarian became an advocate of typographic innovation? What was the press's output in its early years? And, finally, is it useful to explain its marketing strategy in terms of branding? It has been argued that elements of typographic design can be used to identify anonymous editions. ${ }^{2}$ Here, in contrast, the early years of Leuven University Press allow us to approach typographic design as a deliberate branding tool and to explore branding as an explanatory factor - one among others - in the failure or success of eighteenth-century book publishers.

\section{Corneille-François Nelis (1736-1798): an ambitious librarian}

The main character in this narrative, Corneille-François Nelis, was born in Mechelen in 1736, the son of a lawyer. ${ }^{3}$ A brilliant student, he completed his studies at the Leuven Faculty of Arts as primus artium, the best student of his year - a title which usually heralded an academic career. He soon became head of the college for Mechelen students in Leuven (1757), and some months later, at the age of 21, he was appointed custodian of the central university library. Subsequently, he graduated in theology and took holy orders in 1760, before which he had already been appointed canon of Saint-Peter's in Leuven. Nelis's star rose swiftly. As a librarian, he was also a fast mover. ${ }^{4}$ Until then, the University had mainly considered its librarians as caretakers of its central library. The library policy, however, had been under the control of five academics delegated by the University's faculties. Nelis did not intend to put up with this situation. He was particularly eager to extend the library collection, to bring it up to date and to increase its acquisition budget. His first idea to achieve this was to make every student taking a degree in one of the higher faculties pay a fee that would go directly to the library's account. Despite protest by the Faculty of Theology, which feared a decline in the number of students intending to take a degree, the idea was soon ratified by the government, which also extended the system of legal deposit (already in use at the Brussels Royal Library) to Leuven's central university library. ${ }^{5}$ Another of Nelis's suggestions was the creation of a new publishing house, a university press. This idea would soon have far-reaching consequences for scholarly practice in the context of the University. ${ }^{6}$

\footnotetext{
${ }^{2}$ F.A. Janssen, 'Layout as means of identification?', in: Id., Technique and design in the history of printing. 26 essays ('t Goy-Houten 2004), pp. 101-11 (originally published in Quaerendo, 25 [1995], pp. 46-58).

${ }^{3}$ W.J.H. Prick, C.-F. de Nelis, un homme d'Église libéral au siècle des Lumières (1736-1784), Nancy 1942, and Id., Corneille-François de Nelis, 18e et dernier évêque d'Anvers (1785-1798): un évêque humaniste et homme d'action à la fin de l'Ancien Régime, Louvain 1954. On Nelis's works see C. de Clercq, 'Corneille-François de Nelis. CEuvres complètes', in : Bibliotheca Belgica. Bibliographie générale des Pays-Bas, ed. M.T. Lenger, vol. 4 (Bruxelles 1979), pp. 433-74.

${ }^{4}$ For Nelis's action as a librarian, cf. Universiteitsbibliotheek Leuven, 1425-2000: sapientia aedificavit sibi domum, ed. C. Coppens, M. Derez, J. Roegiers (Leuven 2005), pp. 63-6.

${ }^{5}$ By the imperial ordinance of 3 February 1759: Recueil des ordonnances des Pays-Bas autrichiens. Troisième série : 1700-1794, ed. J. de le Court, vol. 8 (Bruxelles 1894), pp. 276-7.

${ }^{6}$ The only substantial article on the history of the eighteenth-century Leuven University Press, even today, is J. Roegiers, 'De academische drukkerij van de oude universiteit Leuven (1759-1797)', Documentatieblad Werkgroep Achttiende Eeuw, 52-4 (1982), pp. 143-61. The eighteenth-century press is not to be confused with
} 
At first, Nelis considered the creation of the new publishing house merely as a tool to support the library budget and to extend the library collection. By printing scholarly texts that were no longer available, the university press would facilitate an exchange of books with other publishers, which would benefit the library. Moreover, by executing all the academic printing tasks, it would raise additional finances to buy books on the market. At a very early stage, however, Nelis began to emphasize additional advantages of the new press. In letters written shortly after the launch of his first idea, he suggested that the press could be developed into a strong instrument for the advancement of knowledge and the overall revival of intellectual life, and even of 'good taste', in the Southern Low Countries. In his view, local typography had fallen into decay, and it was a moral duty to seize the opportunity and create a press that would be innovative in terms of design and typographical quality. Thus, he wrote that 'the reanimation of our presses is almost the only way to encourage literature in our country' ${ }^{7}$, and even more explicitely: 'In this way, we believe that one day, we will walk in the footsteps of Froben, Gryphius, E[s]tienne, Plantin etc., and even surpass them. ${ }^{8}$

\section{Nelis's taste for typography}

It may seem odd that a university librarian believed so strongly in the importance of typography. Clearly, Nelis was an exceptional young man in this respect as well. To be sure, like many fellow academics, he gradually built his own private library - although this may only have become a substantial activity after his appointment as a canon in Tournai (1764) and later still, from 1784 onwards, when he was bishop of Antwerp. In these later years, he made use of several elaborate engraved bookplates. His library, sold at several auctions in the first decades of the nineteenth century, was famous for its rich collection of manuscripts on the history of the Low Countries. It is also likely to have included some very fine printed editions. ${ }^{9}$ However, there are more convincing facts pointing towards Nelis's special interest in beautiful, well-designed books and in elegant typographic design.

In 1763, some years after the creation of the University Press, Nelis installed a printing press in his brother's house, also in Leuven. On this private press - which was not officially registered and therefore violated the laws on printing and publishing - he printed ${ }^{10}$ two of his own short philosophical texts: Fragment

the academic press that was established in Leuven in 1971, about which more information at http://upers.kuleuven.be/en.

7 'Ranimer nos presses, c'est quasi le seul moien de faire fleurir davantage chez nous les lettres.' (Letter by Nelis to De Neny from Leuven, 20 December 1760, Brussels, State archives, Manuscripts, 2022.)

8 ' $C$ 'est ainsi que l'on se flatte de marcher un jour à la suite des Froben, des Gryphius, des E[s]tienne, des Plantin etc. et même de les devancer.' (Letter by C.F. Nelis to the Brussels paper-owner Jean-Henri Maubert de Gouvest from Leuven, 17 August 1759, Leuven, State Archives, Ancient University of Leuven, 229.) On Gouvest, publisher of the Mercure historique et politique des Pays-Bas, cf. J. Vercruysse, 'Candide journaliste. J.H. Maubert de Gouvest gazetier à Bruxelles 1758-1761)', Cahiers bruxellois, 19 (1974), pp. 46-83.

${ }^{9}$ On Nelis's bookplates, see B. Linnig, Bibliothèques et ex-libris d'amateurs belges aux XVIIe, XVIIIe et XIXe siècles (Paris 1906), pp. 6o-3 and Id., Quelques ex-libris belges anciens (Paris 1921), pp. 44-5. On his activities as a bibliophile C. de Clercq, 'Deux bibliophiles : Corneille-François Nelis et Paul-Antoine Wins', De Gulden Passer, 35 (1957), pp. 148-78, and Id., art. cit. (n. 3), pp. 438-9.

${ }^{10}$ It is not clear if Nelis printed them himself or had them printed by someone else. C. de Clercq, art. cit. (n. 3), p. 433 , mentions a letter by Nelis from 1785 in which he tells that he had printed the Fragment sur les principes himself. But Nelis's friend J.N. Paquot, in a letter to De Neny dated 8 January 1764, wrote: 'Vous savez que le 
sur les principes du vrai bonheur: discours à Lysimaque, and Alexis: fragment d'institution d'un prince. <fig. 1> Both 'fragments' were produced in 1763 and had the imprint 'A Louvain, de l'Imprimerie de l'Université', although they had not been printed by the official university press. Nelis published these small volumes in a very limited edition of only a few copies. Today, only one and three copies respectively have been identified in public collections, with three of these four known copies being small gilded morocco-bound volumes. ${ }^{11}$ Their typographic design is quite amazing and reflects an uncommon taste for neoclassical typography, with only the quality of the type and layout used as instruments to achieve beauty and visual appeal. Thus, only six years after the publication of John Baskerville's Virgil (Manchester 1757) - the neoclassical prototype -, an amateur of fine editions living in the Low Countries applied a neoclassical design to the products of his private press. It was undoubtedly one of the earliest examples of this new direction in typography in that part of Europe.

Nelis's involvement in manifold activities over the following decades, however, prevented him from further developing his typographic skills. He left Leuven in 1768, having become bored with librarianship, and after it had become clear to him that he would never be accepted as a university professor because of the aversion his overzealous attitude had caused. Among other things, he became one of the first members of the Brussels Imperial and Royal Academy in 1772, was intensely involved in government education policy after the suppression of the Jesuit colleges in 1773, and he was appointed Bishop of Antwerp in 1784. In the latter capacity, he became one of the leaders of the revolt against the Austrian Emperor Joseph II and the subsequent Republic of the United Netherlands (1789-1790). In his last years he was forced into exile after the invasion of the country by French revolutionaries (1794). This period of exile in Italy gave him the opportunity to make contact with none other than Giambattista Bodoni in Parma, for whose work he felt infinite admiration and who he visited on several occasions. He also exchanged numerous letters with him in the years 1794-1796 and most of his final works appeared through the Officina Bodoni. Their correspondence reveals that Nelis was very interested in the way Bodoni designed his texts. ${ }^{12}$ One of the works was illustrated with a fine engraved portrait, showing Nelis in his final years, shortly before his death in Florence on 21 August 1798. $<$ fig. 2>

\section{Meeting the government's intentions}

However strongly he believed in it, Nelis would never have succeeded in realizing the university press if his ideas had not been shared by strong allies, both in Leuven, where the éminence grise of the Faculty of Theology, Jean-Joseph Guyaux (1684-1774), was one of Nelis's strongest supporters, but even more so in government circles in Brussels. At this point, another major character enters the narrative: Patrice-François de Neny (1716-1784), head of the Privy Council from 1758, and thus the highest native official of the Austrian

petit ouvrage de M. Nelis a été connu ici, malgré le petit nombre d'exemplaires qu'il en avoit fait tirer [...]. On a d'abord crié beaucoup, sur ce qu'il l'avait fait imprimer chez lui.' (Brussels, State Archives, Manuscripts, 2022).

${ }^{11}$ Fragment sur les principes: only copy in Brussels, Royal Library of Belgium, VH 4476A. Alexis: 2 copies in Brussels, Royal Library of Belgium, VH 4876A and II 93723A, and one copy in Leuven, Central University Library, CaaA2016.

${ }^{12}$ C. de Clercq, 'Corneille-François Nelis et Jean-Baptiste Bodoni', De Gulden Passer, 30 (1952), pp. 85-110, and Id., 'L'évêque d'Anvers C.F. de Nelis et le monde italien du livre', Gutenberg Jahrbuch, 36 (1961), pp. 185-92. 
government in Brussels. ${ }^{13}$ In 1754, he had been appointed royal commissioner for the University. This new function had been created in order to modernize university teaching by the introduction of new scientific developments, and to mould the University into an instrument of Habsburg politics, entailing the centralization and enhancement of government control. To cope with this challenging assignment, De Neny had built a network of agents and informants, with Jean-Joseph Guyaux acting as a node. Apparently, it was Guyaux who had recommended the young Nelis to De Neny when he was looking for a tutor for his oldest son, Philippe-Goswin, a student at Leuven University from 1756. Moreover, it was because De Neny wanted to extend his influence over the University by controlling its library that he had Nelis appointed as its librarian in 1758.

From that moment on, Nelis and De Neny started an intense confidential correspondence, of which numerous letters have been preserved. ${ }^{14}$ Nelis acted as a local agent of De Neny and informed him of the state of mind of the Leuven academics. Gradually, he also formulated ideas about the extension of the library budget and the creation of a university press. His ideas were very often put into practice by De Neny, swiftly and with considerable persuasiveness. De Neny wanted changes implemented without delay, and he did not hesitate to send letters of reminder to the head of the University whenever he felt the implementation of his decisions was being postponed. This is precisely what happened with respect to the plans for the university press: Nelis came up with the idea, he called upon De Neny when the opportunity arose, and De Neny put the idea into practice, paying little attention to the resistance of several other interested parties in Leuven.

\section{The start of the university press}

It is important to emphasize that from the early days of the University, the book trade and publishing activities in Leuven had been monopolized by accredited booksellers and printers. They had to register as members ('suppositi') of the University and were subject only to the academic authorities, and not to the town administration or to any central government body. The University had issued and regularly updated its own set of regulations regarding the printing and selling of books within its jurisdiction. The last update had been published very recently, in 1750, only a few years before Nelis came up with his idea for a central university press. ${ }^{15}$ Obviously, the accredited printers were concerned when they heard of the plans. When a talkative type-founder from Amsterdam came to Leuven to present his letter samples to Nelis, he also made contact with other Leuven printers, told them about the new schemes, and in doing so created much discontent among the registered Leuven printers.

\footnotetext{
${ }^{13}$ B. Bernard, Patrice-François de Neny (1716-1784). Portrait d'un homme d'Etat (Etudes sur le XVIIIe siècle, 21; Bruxelles 1993).

${ }^{14}$ Fragments of the correspondence concerning the university press between Nelis and De Neny in Brussels, State Archives, Manuscripts, 2022 and in Leuven, State Archives, Ancient University of Leuven, 218-219, 229. Five letters have been published by $C$. de Cercq, 'Cinq lettres de Corneille François Nelis à Patrice François de Neny', Bulletin de l'Institut historique belge de Rome, 15 (1935), pp. 133-44.

${ }^{15} \mathrm{P}$. Delsaerdt, 'Les règlements sur la production et la vente des livres, promulgués par l'ancienne université de Louvain. Édition critique', Lias, 17 (1990), pp. 63-89, and Id., 'Printers and printing policy at Leuven University, 15th-18th centuries', in: New perspectives in book history. Contributions from the Low Countries, ed. M. van Delft, F. de Glas, J. Salman (Bijdragen tot de geschiedenis van de Nederlandse boekhandel, Nieuwe Reeks vol. 7; Zutphen 2006), pp. 49-64.
} 
However, their initial resistance did not alter the plans of the Brussels government: on 11 August 1759, the representative of the Austrian imperial authority in the Low Countries, Charles-Alexander of Lorraine, officially created and patented the university press, thereby following almost every detail of the plans Nelis had committed to paper some months earlier. ${ }^{16}$ Among other things, the regulation of 11 August granted the new press a monopoly over the printing of student theses, at least for the faculties of Law and Medicine (the printers holding that privilege having recently passed away). A building to house the press was found, a young printer was appointed, and type of the highest quality was bought from firms in Haarlem, Amsterdam and Paris - although not exclusively abroad. At the instigation of De Neny, type was also bought from the Brusselsbased punch-cutter and type-caster Jacques-François Rosart (1714-1777). This Namur-born craftsman had worked as an independent punch-cutter in Haarlem from 1740, but had faced fierce competition in this capacity from Joan Michael Fleishman, a German punch-cutter who worked extensively for Enschedé. Rosart had thus returned to the Austrian Netherlands, to Brussels, where he flourished between 1759 and 1777, with considerable support from the Brussels government. ${ }^{17}$ In addition to this new type material, Nelis also bought the type that had been left by the former printers who had worked for the faculties of Law and Medicine, and material from Theodorus Zangrius, another Leuven printer who had decided to leave the profession when he heard that a university press would be commencing.

\section{The press's first publications}

Let us now have a look at the first publications that were issued by the university press. While research that carefully reconstructs the press's total output is yet to be done, it has been estimated that from its foundation in 1759 until its closing in 1797, the Typographia Academica produced some 80 books, 12,000 theses and dissertations, and an incalculable amount of printed administrative material and academic ephemera. ${ }^{18}$ When one studies some of the editions that were published from the inception of the press in 1759 through to Nelis's departure from Leuven in 1768 , one is struck - and somewhat puzzled - by the fact that the publications bearing the imprint 'Typis Academicis', 'E Typographia Academica', or 'De I'Imprimerie académique' are far from being uniform in appearance or style.

Firstly, there is printed material that does not differ substantially in quality from that usually produced by other Leuven printing presses. This is the case for student theses that - according to the imperial decree of 1759 - had to be printed by the university press. For these broadsides and brochures, apparently, the typesetter chiefly used the old type that had been bought from the Leuven printers who had passed away or had left the business, and there was not much care taken with the quality of the layout. Undoubtedly, these publications only very rarely met the high standards that Nelis had advocated shortly before. ${ }^{19}$

\footnotetext{
${ }^{16}$ The imperial ordinance of 11 August 1759 in Recueil des ordonnances des Pays-Bas autrichiens. Troisième série : 1700-1794, ed. J. de le Court, vol. 8 (Bruxelles 1894), pp. 328-9.

${ }^{17}$ The type specimen of Jacques-François Rosart Brussels 1768. A facsimile with an introduction and notes, ed. F. Baudin, N. Hoeflake (Amsterdam 1973).

${ }^{18} \mathrm{~J}$. Roegiers, art. cit. (n. 6), p. 158.

${ }^{19}$ Numerous theses printed by the University Press are currently part of the Collectio academica antiqua of Leuven Central University Library. I owe thanks to Diederik Lanoye and An Smets for their help in finding
} 
Secondly, the university press also produced fully fledged books, and it did so from the very beginning: these included old text editions that were no longer available on the market, handbooks for academic teaching, and reference books. In the 1760 edition of the Orationes theologicae by the sixteenthcentury theologian Guillelmus Estius, a short introduction by the 'novus editor' informed the reader about the establishment of the university press. Here it was emphasized that the press had been set up on behalf of the royal authority and by people aiming to sustain the bonae literae, and that in the near future it would produce 'a richer treasure of exquisite, voluminous and influential books'. ${ }^{20}$ This combination of formal quality, relevant content and impressive physical size was achieved some years later, when Jean-Noël Paquot published his magnum opus, the Mémoires pour servir à l'histoire littéraire des dix-sept provinces des Pays-Bas, de la Principauté de Liège et de quelques contrées voisines. Paquot was professor of Hebrew at Leuven and acted as a local informant for the Brussels government, just like his friend Nelis, whom he would succeed as the university librarian in $1768 .{ }^{21}$ His Mémoires, an erudite bio-bibliography of scholarly authors from the Low Countries, were published from 1765 to 1770 , simultaneously in a three-volume folio edition and an eighteenvolume octavo edition. This monumental bibliography has justly been characterized as the best work that ever came from Leuven University Press from its start in 1759 until 1797, when both the University and its press were abolished by the French revolutionary regime. The university press deliberately invested more energy in the design of this more voluminous work.

It is striking, however, that it also did this for some smaller publications. A legal thesis that was defended by a Ghent student in 1767, for example, was very stylish: it included the distinctive printer's mark of the Typographia Academica on the title page, a full-page engraving with the coat of arms of the county of Flanders as a frontispiece, and a fine ornament introducing the first chapter - not what one would call the usual, routine design for a thesis. The fact that it was dedicated to the provincial states of Flanders probably explains the almost luxurious design. ${ }^{22}<\mathrm{fig} .3>$

More convincing still in this respect are two small works by Corneille-François Nelis himself and his brother Dominicus, who was a professor at the Leuven Faculty of Law. Both of these small brochures quite faithfully reflect the neoclassical design that we have already observed when talking of Nelis's privately produced booklets of 1763 . The inaugural lecture of Dominicus Nelis is one of the earliest known productions if not the earliest - of Leuven University Press: the lecture was delivered on 16 August 1759 and must have been published shortly afterwards at the latest. ${ }^{23}$ Together with the oration that Corneille-François Nelis gave

these copies; most of the theses have been digitized and can be accessed through the online library catalogue at http://bib.kuleuven.be/.

${ }^{20}$ 'Novus editor lectori s[alutem]. Coepit ante menses aliquot Lovanii regia auctoritate, et virorum quorundam de bonis literis bene mereri studentium opera institui Typographia Academica, uberiorem hisce regionibus librorum exquisitiorum administratura supellectilem; [...] exspectantur molis ac momenti majoris ex ea proditura volumina.' (G. Estius, Orationes theologicae. Editio nova [Lovanii 176o], p. 1.)

${ }^{21}$ On Paquot as a university librarian, cf. Universiteitsbibliotheek Leuven, 1425-200o (op. cit. [n. 4]), p. 66.

${ }^{22}$ J.B.B. Rigauts, Repetitio de collatione bonorum (Leuven 1767); a copy in Leuven, Central University Library, CaaTHJg004; a digitized version is accessible through the online library catalogue at http://bib.kuleuven.be/.

${ }^{23}$ D.J.H. Nelis, Oratio quam in conventu academico Lovanii habuit [...] quum munus suum iniret ([Leuven 1759]); a copy in Stedelijke Erfgoedbibliotheek-Stadsarchief Mechelen, M.06725(b). 
in Brussels on the death of Emperor Francis I in November $1765{ }^{24}$ it bears witness to the highly innovative, almost avant-garde design that the university press was able to produce. <fig. $4>$ Both publications put the beauty of the naked letter first and rejected every kind of ornament, not unlike the new typographic models that had been developed not so long before by John Baskerville in Birmingham and Robert Foulis in Glasgow. This becomes very clear when we compare the title page of Nelis's funeral oration produced by Leuven University Press with the title page of the same text (though in a bilingual Latin and French edition) published by the Brussels printer Josse vanden Berghen. ${ }^{25}<$ fig. $5>$ The Leuven version is designed to provide a strikingly limpid, calm and lucid appearance, while the Brussels title page leaves the reader with a busy, nervous and rather chaotic impression. The bilingual edition created a nice opportunity for a mirror-like design, but this opportunity was clearly not seized by the Brussels printer, not even with regard to the positioning of typographical ornaments.

\section{Branding}

In some of its first productions, Leuven University Press reached a high level of typographical quality. The design of these publications allow the press to be ranked among the earliest European publishing houses to have adopted - at least partially - neoclassical aesthetics, sometimes referred to as typographie pure. What is interesting is that this was done deliberately, with the intention of making a difference and distinguishing the new Leuven press from other players in the field of scholarly publishing. In this context, Nelis's words, quoted at the start of this article ('nothing but quality of content and beauty of execution'), take on their full significance. His ambition was nothing less than to create a brand. Perhaps this brand approach will help us to better understand both the intentions of the press from the very beginning and the reasons why it failed to fulfil its promises in the long run.

A leading handbook on brand management, Kevin Lane Keller's Strategic Brand Management, refers to the definition of a brand by the American Marketing Association: a brand is 'a name, term, sign, symbol, or design, or a combination of them, intended to identify the goods and services of one seller or group of sellers and to differentiate them from those of competition'. ${ }^{26}$ In other words, brands create a difference 'from other products designed to satisfy the same need'. ${ }^{27}$ Keller also tells us that 'brands can signal a certain level of quality so that satisfied buyers can easily choose the product again', and that 'in this sense, branding can be seen as a powerful means to secure a competitive advantage'. ${ }^{28}$ It would be absurd, of course, to pretend that our eighteenth-century librarian, however brilliant he was, understood the mechanisms and the full potential

\footnotetext{
${ }^{24}$ C.F. Nelis, Oratio in funere Francisci I (Lovanii 1765); a copy in Leuven, Central University Library, CaaA1437; a digitized version is accessible through the online library catalogue at http://bib.kuleuven.be/. The copy that Nelis presented to P.F. de Neny is now in Vienna, Österreichische Nazionalbibliothek, 66.k.27. The morocco binding is very similar to the volumes discussed above, n. 11.

${ }^{25}$ C.F. Nelis, Oraison funèbre de François I / Oratio in funere Francisci I (Bruxelles 1765); a copy in Leuven, Central University Library, CaaA2267 and one in Antwerp, University Library, MAG-P 12.1475.1.

${ }^{26}$ K.L. Keller, Strategic brand management. Building, measuring, and managing brand equity ( $3{ }^{\text {rd }}$ edition; Upper Saddle River 2008), p. 2. (A $4{ }^{\text {th }}$ edition of this book appeared in 2013.) I owe thanks to prof. dr. Patrick De Pelsmacker for pointing me to this handbook.

${ }^{27}$ K.L. Keller, op. cit. (n. 26), p. 5.

${ }^{28}$ K.L. Keller, op. cit. (n. 26), p. 9.
} 
of the brand 'Typis Academicis'. However, the analysis of his correspondence reveals that he was aware of the fact that in order to be successful in the scholarly publishing market, the new university press had to do more than merely create a fine printer's device. According to Nelis, one of the features giving the press its own identity and differentiating it from its competitors was that quality of content went hand in hand with quality of design.

To be sure, twenty-first-century handbooks on brand building and brand management do not provide comprehensive frames of reference for explaining how the idea of branding was or was not applied in previous centuries. Nevertheless, they offer ideas and analytic tools that may help us understand why brands worked or indeed did not work - in the past. In his account of the history of Leuven University Press, Jan Roegiers described how the publishing house gradually lost its innovative character and fell into standard practice and then decay, especially after Nelis's final departure from Leuven in $1768 .{ }^{29}$ Additionally, the same author has shown that the first publications failed to meet any real public demand, and that the absence of a strong distribution network led to commercial failure, even after the creation of a university bookshop in 1769. The branding perspective may offer a useful complement to this analysis.

Undeniably, Corneille-François Nelis understood the importance of creating a specific identity for the new publishing house. His plea for exquisite typography arose from his personal penchant for fine editions, but also from his intuitive understanding of the meaning and power of what is called a brand today. This understanding is generally considered a basic condition for successful brand management. In addition, the brand 'Typis Academicis' had the potential to be associated with powerful institutions: both the University's central library, which was growing in importance almost simultaneously with the press, and of course the venerable University itself, with its monopoly on higher education in the Southern Low Countries. In this respect, the Leuven case did not differ fundamentally from the earlier examples of university presses, both in Oxford and Cambridge. (The re-foundation of Cambridge University Press in the 169os, by the way, certainly presents more than one analogy with its Leuven counterpart: it was the result of the initiative of a (royal) librarian, Richard Bentley, and of the support given by the Chancellor of the University, the Duke of Somerset. A major difference, however, was that Cambridge had John Baskerville himself appointed as University Printer in $\left.175^{8} \ldots{ }^{30}\right)$ At the same time, it is striking to see how many of K.L. Keller's 'deadly sins of brand management ${ }^{\prime 31}$ are perfectly illustrated by the Leuven case.

To create a successful brand, it is critical to understand the needs of consumers and thereby ensure that customers 'have the right type of experience with products and services'. The current concept of customer-based brand equity entails the conviction that 'the power of a brand lies in what resides in the minds of customers'. ${ }^{32}$ What is known about the processes that led to the foundation of the University Press suggests quite the opposite. It was developed top-down by an ambitious and somewhat overzealous young individual. His ideas certainly met the intention of the government to extend its control over the University, but not

\footnotetext{
${ }^{29}$ J. Roegiers, art. cit. (n. 6).

${ }^{30}$ D. McKitterick, A History of Cambridge University Press, vol. 2: Scholarship and Commerce 1698-1872 (Cambridge 1998), pp. 45-7 and 196.

$3^{31}$ K.L. Keller, op. cit. (n. 26), p. 643.

${ }^{32}$ K.L. Keller, op. cit. (n. 26), p. 48.
} 
necessarily the needs of the Press's customers. Although some of the University's professors were certainly adherents of Nelis's convictions, it would be an exaggeration to state that Leuven University Press was driven by a concern for what its future customers had in mind.

Moreover, the power of a brand strongly depends on complementarity and consistency. ${ }^{33}$ Different brand elements have to be defined in such a way that a consistent image is created. Applied to the Leuven University Press, this means that each and every one of its products should have reflected the same concern for typographical quality. In this respect, the press's monopoly over all kinds of academic publications created huge opportunities. However, they were not seized, as we have seen: the press failed to apply the novel aesthetics to all its productions, thereby missing the opportunity to convince its main customers - the Leuven academics and their students - of its added value. It is not unlikely that some of the press's customers were aware of this and interpreted it as a broken promise. In K.L. Keller's words:

A brand should be a promise and a commitment to consumers, but too often that promise is broken. A common mistake is to set brand expectations too high and then fail to live up to them in the marketing program. By overpromising and not delivering, a firm is worse off in many ways than if it had not set expectations at all. ${ }^{34}$

Finally, a brand needs time and patience. Customers will only pick up brand elements when they come across them on repeated occasions. The brand as a whole needs time to develop and grow, and to regularly update itself in a consistent way, without abandoning its essential features. 'Managing brands over time requires reinforcing the brand meaning and adjusting the branding programme as needed. For brands whose equity has eroded over time, a number of revitalizing strategies are available'. ${ }^{35}$ The designer of the brand 'Typis Academicis', Corneille-François Nelis, definitely lacked the consistency that was needed to guarantee a longterm approach. As early as 1768, he left Leuven and its university, a consequence of his disappointment at the hostility towards his pushy attitude, and of the simple fact that he no longer enjoyed the job of university librarian. Apparently, nobody was there to continue along the path he had marked out, let alone to reinforce, adjust and revitalize his vision.

Clearly then, the brand approach demonstrates that the eighteenth-century Leuven University Press had the intention of positioning itself as a unique and innovative player in the field of scholarly publishing, a position for which it had some strong opportunities and instruments at its disposal. However, this approach also shows how the press failed to apply some basic principles of what is currently called brand management. It did not pay attention to the customer response, it lacked a long-term perspective, it set brand expectations too high, and it was not able to apply the main brand element - the high typographical standard - in a consistent way. Nelis's programme of 'quality of content and beauty of execution' was only realized in some early publications. In fact, the typographical renaissance he had dreamed of was very short-lived. Nonetheless,

\footnotetext{
${ }^{33}$ K.L. Keller, op. cit. (n. 26), p. 639.

${ }^{34}$ K.L. Keller, op. cit. (n. 26), p. 643.

${ }^{35}$ K.L. Keller, op. cit. (n. 26), p. 641.
} 
the way in which he conceived of the press, both in terms of marketing strategy and design, was truly innovative and in tune with developments taking place elsewhere in Europe. 